\title{
Capability of Pocket Penetrometer to Evaluate Unconfined Compressive Strength of Baghdad Clayey Soil
}

\author{
Azhar Sadiq Yasun \\ Civil Eng. Dep. \\ Al-Nahrain university, Baghdad, IRAQ \\ azhar28091983@gmail.com \\ Received: 02-Feb.-2017 Revised: 05-May-2017 Accepted: 05-Nov.-2017 \\ http://doi.org/10.29194/NJES21010066
}

\begin{abstract}
Unconfined compressive strength represents an important parameter for soil investigation report test results because the values of cohesion and allowable bearing capacity can directly obtained from the relevant test especially if the clayey soil layers are found at sufficient enough depth above water table level.

This paper deals with simple comparison (based on (31) soil samples) between unconfined compressive strength $\left(\mathrm{q}_{\mathrm{u}}\right)$ obtained by using the pocket soil penetrometer tool and the unconfined compressive strength using the conventional test for the same sample penetrated by the pocket penetrometer with different soil moisture contents. Two triaxial specimens, sample type-1with dimensions $38 \times 79 \mathrm{~mm}$ and type-2- with dimensions $33 \quad \mathrm{X} \quad 79 \mathrm{~mm}$ (diam. $\mathrm{X}$ height)) prepared in the libratory.

It was found that the results refers that soil pocket penetrometer readings are closed enough to the results that obtained from the unconfined compression test result with certain conditions.

The average percentage of difference between penetrometer readings and unconfined compression test result values was (1.103\%) for sample type-1- and (1.53\%) for sample type -2-.

The maximum moisture content for all tests samples was (27.3\%) and the minimum was $(14.7 \%)$ while the average moisture content was(20.9\%).
\end{abstract}

Keywords: Pocket Soil Penetrometer, Unconfined Compressive Strength, allowable bearing capacity.

\section{Introduction}

The pocket soil penetrometer represents direct simple tool used in the site for soil investigation to evaluate unconfined compressive strength for clayey and clayey silt soils.

In general the test procedure of using pocket soil penetrometer initially depends on ASTM standard No.WK27337 titled as "new test method for pocket penetrometer test". The ASTM official web site for this standard committed that "the title and scope are in draft form and are under development within this ASTM committee”[1]
There are many references that deal with this tool in detail. The laboratory manual of test procedures, may 2016 , reveals that the Pocket Penetrometer the method indicates consistency and approximate unconfined compressive strength of in-place or undisturbed Shelby tube cohesive soil samples[2].

The report on the strength measurements of archive $\mathrm{K}$ basin sludge using a soil penetrometer, refers that industrial use of the pocket penetrometer tool is to check the strength of the basin sludge. Under current plans, water jets will be used to help mobilize $\mathrm{K}$ basin sludge for retrieval from the (Sludge Transport and Storage Containers) STSCs after interim storage. It is important to determine whether water jets can mobilize and erode the stored $\mathrm{K}$ basin sludge from the STSCs. Shear strength is known to be a key property to determine whether water jets can mobilize sludge from the STSCs[3].

Accordingly, the unconfined compressive strengths of archive $\mathrm{K}$ Basin sludge samples and sludge blends were measured using a pocket penetrometer modified for hot cell use. Based on known correlations, the unconfined compressive strength values measured by the pocket penetrometer were converted to shear strengths. Using inventory logs, twenty-six sludge samples were identified and selected as potential candidates for sludge strength measurement[3]. In the test procedure for manual for description identification of soils presented by Texas department of transportation, August 1999, this text depends the penetrometer reading for describe the soil consistency as seen in the Plate1-[4].

For soil properties behind retaining wall unless the backfill soil parameters are provided by the geotechnical consultant, it is common to estimate them conservatively as follows[5]:

$$
\begin{gathered}
\emptyset=30 \text { to } 36^{\circ}\left(\text { usually } 32 \text { to } 34^{\circ}\right) \\
\gamma=16.5 \text { to } 17.5 \mathrm{kN} / \mathrm{m}^{3}
\end{gathered}
$$

It is necessary to obtain values of $\phi, \gamma$, and cohesion c for the original ground (where it will be excavated vertically to make space for a wall). Direct shear or direct simple shear tests on good- 
quality tube samples provide the best soil parameters, since a retaining wall is a plane strain case. Most testing is triaxial (if any is done) and it is either unconsolidated or consolidatedundrained. Many test laboratories do not have test equipment. The base soil plane strain parameters $\phi, \quad \gamma$, and cohesion $\mathrm{c}$ can be obtained (or estimated) so that sliding stability and bearing capacity can be computed[4]. It is common practice, however, to obtain $S_{u}=q_{u} / 2$ for any cohesive soil, where qu is obtained from SPT data and using either compressive machine testing or a pocket penetrometer (or in combination of them)[5].

Braja M. Das and Khaled Sobhan, 2014 indicate that a pocket penetrometer tool is pushed directly into the soil. The unconfined compressive strength (qu) is measured by a calibrated spring. This device can be used both in the laboratory and in the field[6].

\begin{tabular}{|c|c|c|}
\hline \multicolumn{3}{|c|}{ Iable L-Consistency } \\
\hline Description & Pocket Pen. & Criteria \\
\hline Very Sott & Less than 0.5 & Thumb will penettrate soil more than $25 \mathrm{~mm}$ (1 ii.) \\
\hline Soft & $0.5+10$ & Thumb rili penetratite soil abour $25 \mathrm{~mm}$ (1 in.) \\
\hline Medium siff & 10020 & Thunb vili indent soid about $12.5 \mathrm{sm}$ (1/2in) \\
\hline stiff & 20103.5 & Thumb rill indent sola about $6 \mathrm{~mm}$ (14/4in) \\
\hline Very Sitfif & 35.045 & Thumb will indent sol about $3 \mathrm{~mm}$ (1/8 in.) \\
\hline Hard & Greater than 4.5 & $\begin{array}{l}\text { Thumb vill aot indent soil but teddily indented with } \\
\text { thumbanil. }\end{array}$ \\
\hline
\end{tabular}

Plate 1: Soil consistency according to the pocket penetrometer readings Test Procedure for manual procedure for description identification of soils (Test Procedure for manual procedure for description identification of soils),Texas department of transportation,1999.

\section{Experimental work procedures}

Clayey silt soil brought from one of the Baghdad city project (multi story building) at $4 \mathrm{~m}$ depth below ground surface near Tigris River (the inspector did not recognized the presence of water at this depth).

In this paper test program consists of physical tests to classify soil according to unified classification system, pocket soil penetrometer test and unconfined compressive test.

Two triaxial specimens( sample type-1- with dimensions of about $38 \times 79 \mathrm{~mm}$, sample type -2with dimensions of about 33 X $79 \mathrm{~mm}$ (diam. X height)) stainless steel molds have been used to make sampling from the soil that prepared in lab with selected initial moisture content.

After preparing the unconfined sample according to (ASTM D 2166) [7] the wet weight, diameter and height were measured. Then the penetrating test and unconfined compressive test were carried out. The second wet weight (optional for selected tests) after conducting the unconfined compression test sample failure was measured.

The pocket soil penetrometer test depends on the procedure that adopted in the user guide of the tool and also depends on many foundation and soil manual test procedure references (Humboldt product manual, Appendix A of Soil and Rock Logging, Classification and Presentation Manual, etc).

The main concept of the test is based on using the tool in vertical position with respect to the soil surface and after setting the initial zero reading of the tool ring, the tester penetrates the penetrometer tip (Dia.6.35mm)slightly for $25.4 \mathrm{~mm}$ ( 1 inch) into the soil and reads the ring (the ring slides on the reading penetrometer bar during the tip penetration) as shown in Plate (2) reading directly and recorded it as the unconfined compressive strength of the soil[8].

The tests also comprise measuring sample moisture content before and after the test to check the soil sample consistency since the test is done with different moisture contents. Also the room temperature during the test time is recorded

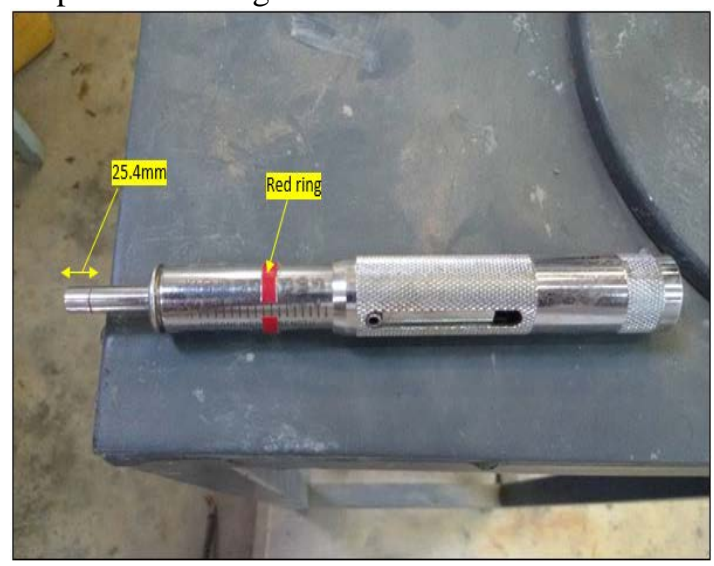

Plate 2: Soil Pocket penetrometer test after testing unconfined compression sample

Soil and Rock Logging, Classification, and Presentation Manual 2010, presents the instruction of using pocket penetrometer and all tests carried out in this paper are done according the steps listed in this manual [9].

The unconfined compression test was carried out with compressive rate equals to (1 percent$\mathrm{mm} / \mathrm{min}$ ) from sample height with respect to specification numbered ASTM D2166, Plate (3) represents failure mode of two typical samples after penetrating and unconfined compression test complete[10].

In laboratory, simple calibration was made using special frame to check the reading of the tool in loading and unloading stages as shown in Plate(4). 


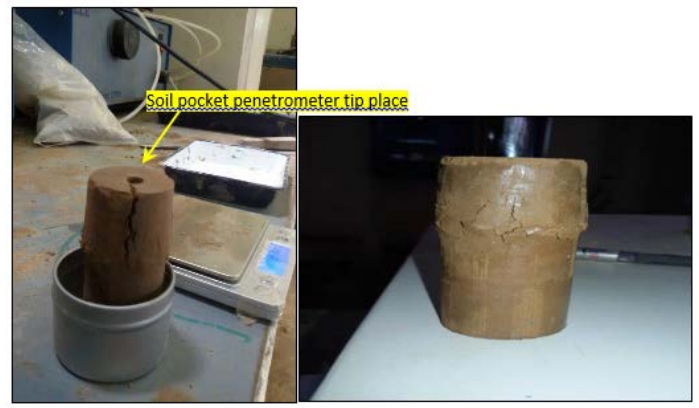

Plate 3: Unconfined compression test sample after failure

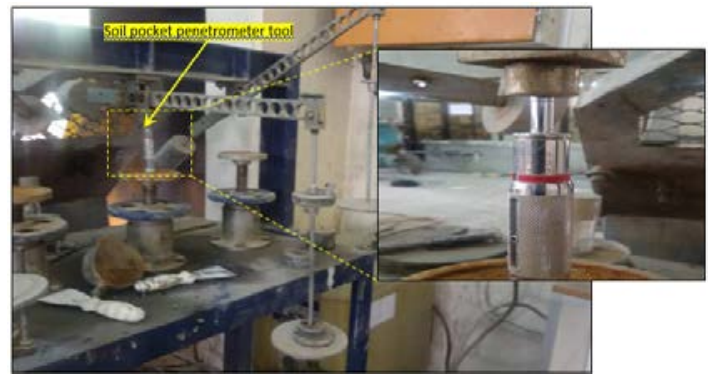

Plate 4: Special frame used to calibrate Pocket penetrometer tool

\section{Test results}

The main physical results obtained for soil sample properties are shown in Table(1)

Table 1: Physical results for soil sample

\begin{tabular}{|c|c|c|}
\hline Soil property & Value & $\begin{array}{c}\text { ASTM } \\
\text { Specification }\end{array}$ \\
\hline Liquid limit & $31 \%$ & D 4318[11] \\
\hline P.I. & 10.81 & D 4318[11] \\
\hline $\mathrm{G}_{\mathrm{s}}$ & 2.63 & D 854 [12] \\
\hline Passing seive No.200 & $69 \%$ & \\
\hline $\begin{array}{c}\text { Clay content(partical } \\
\text { daimeter finer than } \\
0.002 \mathrm{~mm} \text { ) }\end{array}$ & $29 \%$ & D7928[13] \\
\hline $\begin{array}{c}\text { Optimum mositure } \\
\text { content }\end{array}$ & $24 \%$ & D 698 [14] \\
\hline $\begin{array}{l}\text { Xdry maximum } \\
\left(\mathrm{gm} / \mathrm{cm}^{3}\right)\end{array}$ & 1.53 & D 698 \\
\hline $\begin{array}{c}\text { Natural moisture } \\
\text { content }\end{array}$ & $24.3 \%$ & D 2216 \\
\hline
\end{tabular}

The results listed in the Table(1) reveal that the soil can be classified as ML to CL soil using unified classification system, and the natural water content value refers that the depth of soil sampling was near to the water table level.

\subsection{Penetrometer and unconfined compression test results}

According to the experimental procedure, the main tests were conducted and the moisture contents of soils were firstly selected to be close to the natural moisture content, However, the comparison which have been conducted between pocket penetrometer reading and unconfined compression test revealed that the tests have to be carried out with moisture the content lower than the natural one.

Generally the moisture contents range of the samples between (14.73 and 27.26\%). According to tests, it was found that the moisture content less than minimum value made the prepared sample crumbs during penetration process and gave compressive strength value lower than the unconfined compression test results.

Also, the moisture content more than the maximum value made the prepared sample reads directly zero during penetration process and in many cases the sample deflected (bulged) and the shape will not be suitable to complete the unconfined compressive test.

Therefore the selected initial moisture contents were about $20 \%$ because it is regarded as the real natural moisture content to obtain good prediction of unconfined compressive strength computed using the pocket penetrometer tool when compared with the value obtained from unconfined compressive test.

(Fig.1) shows the moisture content variation with respect to test number.

Because of the low moisture losses shown in Table(2), it seems that the difference in moisture before and after test (maximum: 0.97\%, minimum: $0.06 \%$ ) is not significantly affects the unconfined compressive strength value. This check is done to evaluate the clayey soil consistency using initial moisture content value before the penetrometers and unconfined compression tests with respect to the computed moisture content after the unconfined compression test was completed

The main test results shown in Table(3) represent the ultimate unconfined compressive strength for triaxial sample and according to the pocket penetrometer test readings.

The column values of difference ratio (D.R.) between penetrometer reading and unconfined compressive strength is computed as:

Difference ratio $(D . R$.
$\frac{\text { penetrometer reading }}{\text { unconfined compression test result }}$$* 100 \%$

\section{Analysis of test results}

From Table(3) above the average D.R. for sample type -1- was 1.213 the average value was not depends the zero values, and the average values of D.R. for sample type-2- was 1.53. Many relationships can be made based on the results listed in Table(3) to explain the real exception regarding penetrometer reading and unconfined compressive strength.

(Fig.2) shows a comparison between penetrometer reading and unconfined compressive strength with respect to moisture content for sample type-1-. It is clearly that the 
difference between penetrometer reading and unconfined compressive strength becomes small for moisture content ranges between (20\%) and (25\%).

(Fig.3) represents a comparison between penetrometer reading and unconfined compressive strength with respect to moisture content for Samples type-2- It seems that the difference becomes small when the moisture content is exceeds (18\%).

(Fig.3) represents a comparison between penetrometer reading and unconfined compressive strength with respect to moisture content for unconfined compressive strength. Figure-2- shows a comparison between penetrometer reading and unconfined compressive strength with respect to moisture content for sample type-1-. It is clearly that the difference between penetrometer reading and unconfined compressive strength becomes small for moisture content ranges between (20\%) and (25\%).Samples type-2- It seems that the difference becomes small when the moisture content is exceeds (18\%).

Finally (Figs.4and5) show summery of the difference ratio for samples type-1- and samples type-2- with different moisutre contents it is clearly that the samples type-1- results in more relaible and valid readings if compared with samples type-2-.

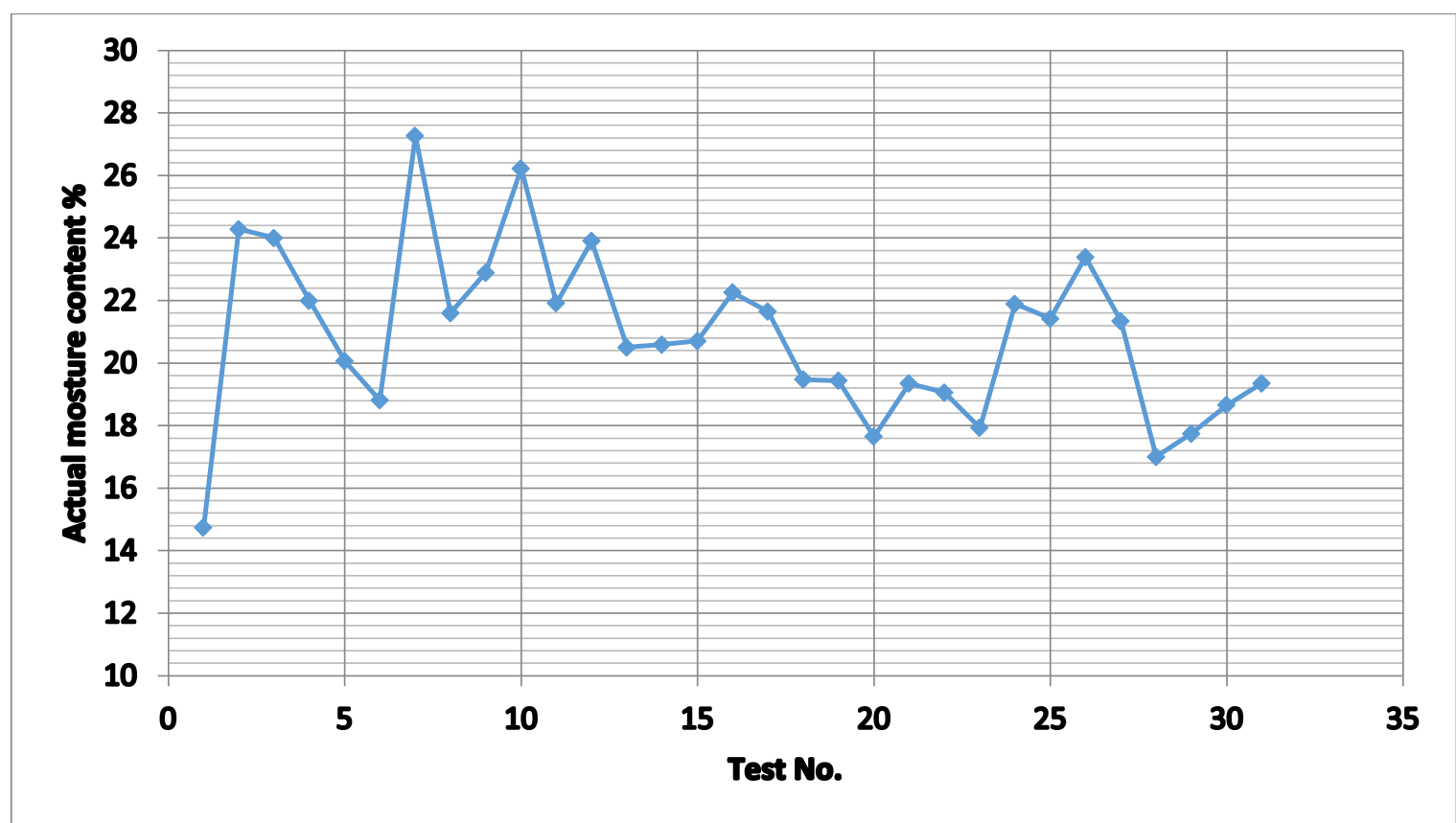

Figure 1: moisture content variation with respect to test number

Table 2: moisture content losses of the test specimens

\begin{tabular}{|c|c|c|c|c|}
\hline $\begin{array}{c}\text { Sample type-1- } \\
\text { Sample type - } \\
\text { 2- }\end{array}$ & $\sim 33 \mathbf{3 8 7 9 m m}$ & & \\
\hline test number & $\begin{array}{c}\text { Actual moisture } \\
\text { content\% }\end{array}$ & $\begin{array}{c}\text { moisture } \\
\text { content\% } \\
\text { after test }\end{array}$ & $\begin{array}{c}\text { moisture losses } \\
\text { \% after test }\end{array}$ & $\begin{array}{c}\text { sample } \\
\text { type }\end{array}$ \\
\hline 11 & 21.91 & 21.68 & 0.24 & 1 \\
\hline 12 & 23.90 & 23.77 & 0.13 & 1 \\
\hline 13 & 20.50 & 20.23 & 0.27 & 1 \\
\hline 14 & 20.59 & 20.23 & 0.36 & 1 \\
\hline 15 & 20.71 & 20.48 & 0.23 & 1 \\
\hline 16 & 22.26 & 22.14 & 0.12 & 1 \\
\hline 17 & 21.65 & 21.51 & 0.13 & 1 \\
\hline 18 & 19.48 & 19.42 & 0.06 & 2 \\
\hline 19 & 19.43 & 19.24 & 0.19 & 2 \\
\hline 21 & 19.34 & 19.11 & 0.23 & 2 \\
\hline 22 & 19.06 & 18.91 & 0.15 & 1 \\
\hline 23 & 17.93 & 17.80 & 0.13 & 0.15 \\
\hline 24 & 21.90 & 21.75 & & \\
\hline
\end{tabular}




\begin{tabular}{|c|c|c|c|c|}
\hline Sample type-1- & $\sim \mathbf{3 8 X 7 9 m m}$ & & & \\
\hline $\begin{array}{c}\text { Sample type - } \\
\text { 2- }\end{array}$ & $\sim 33 X 79 m m$ & & & \\
\hline test number & $\begin{array}{c}\text { Actual moisture } \\
\text { content\% }\end{array}$ & $\begin{array}{c}\text { moisture } \\
\text { content\% } \\
\text { after test }\end{array}$ & $\begin{array}{c}\text { moisture losses } \\
\text { \% after test }\end{array}$ & $\begin{array}{c}\text { sample } \\
\text { type }\end{array}$ \\
\hline 25 & 21.42 & 21.30 & 0.12 & 1 \\
\hline 26 & 23.39 & 23.19 & 0.19 & 1 \\
\hline 27 & 21.34 & 21.01 & 0.33 & 1 \\
\hline 28 & 17.00 & 16.79 & 0.21 & 2 \\
\hline 29 & 17.74 & 17.47 & 0.28 & 2 \\
\hline 30 & 18.66 & 17.69 & 0.97 & 2 \\
\hline 31 & 19.36 & 19.14 & 0.21 & 2 \\
\hline
\end{tabular}

Table 3: Compareson between the ultimate unconfined copressive strength computed from penetrometer and unconfined compressive test.

\begin{tabular}{|c|c|c|c|c|c|c|c|}
\hline \multirow{2}{*}{\begin{tabular}{|l|}
$\begin{array}{l}\text { Sample } \\
\text { type -1- }\end{array}$ \\
Sample \\
type -2- \\
\end{tabular}} & \multirow{2}{*}{$\begin{array}{c}\sim 38 \times 79 \mathrm{~mm} \\
\sim 33 \times 79 \mathrm{~mm}\end{array}$} & \multirow{3}{*}{$\begin{array}{l}\text { Sample } \\
\text { type }\end{array}$} & \multirow{2}{*}{\multicolumn{2}{|c|}{$\begin{array}{l}\text { Ultimate unconfined } \\
\text { compressive strength }(\mathrm{kPa})\end{array}$}} & \multirow{3}{*}{ D.R.\% } & \multirow{3}{*}{$\begin{array}{c}\text { Average } \\
\text { D.R.\% for } \\
\text { sample } \\
\text { type-1- }\end{array}$} & \multirow{3}{*}{$\begin{array}{c}\text { Average } \\
\text { D.R.\% } \\
\text { for } \\
\text { sample } \\
\text { type-2- }\end{array}$} \\
\hline & & & & & & & \\
\hline Test no. & $\begin{array}{l}\text { moisture } \\
\text { content } \%\end{array}$ & & $\begin{array}{l}\text { Penetromete } \\
\text { r test }\end{array}$ & $\begin{array}{c}\text { Unconfined } \\
\text { compression } \\
\text { test }\end{array}$ & & & \\
\hline 1 & 14.73 & 1 & 245.17 & 140.81 & 1.74 & & \\
\hline 2 & 17 & 2 & 299.1 & 153.08 & 1.95 & & \\
\hline 3 & 17.65 & 2 & 284.39 & 183.43 & 1.55 & & \\
\hline 4 & 17.74 & 2 & 220.65 & 170.47 & 1.29 & & \\
\hline 5 & 17.93 & 2 & 343.23 & 164.22 & 2.09 & & \\
\hline 6 & 18.66 & 2 & 245.17 & 158.65 & 1.55 & & \\
\hline 7 & 18.81 & 1 & 50.01 & 83.36 & 0.6 & & \\
\hline 8 & 19.06 & 2 & $\begin{array}{l}196.13 \\
\end{array}$ & 116.11 & 1.69 & & \\
\hline 9 & 19.34 & 2 & 156.91 & 139.39 & 1.13 & & \\
\hline 10 & 19.36 & 2 & 205.94 & 135.31 & 1.52 & & \\
\hline 11 & 19.43 & 2 & 122.58 & 122.94 & 1 & & \\
\hline 12 & 19.48 & 1 & 176.52 & 93.22 & 1.89 & & \\
\hline 13 & 20.07 & 1 & 53.94 & 78.68 & 0.69 & & \\
\hline 14 & 20.5 & 1 & 171.62 & 86.86 & 1.98 & & \\
\hline 15 & 20.59 & 1 & 171.62 & 89.3 & 1.92 & & \\
\hline 16 & 20.71 & 1 & 232.91 & 80.02 & 2.91 & 1.2135 & 1.53 \\
\hline 17 & 21.34 & 1 & 73.55 & 75.09 & 0.98 & & \\
\hline 18 & 21.42 & 1 & 58.84 & 62.38 & 0.94 & & \\
\hline 19 & 21.6 & 1 & 73.55 & 75.39 & 0.98 & & \\
\hline 20 & 21.65 & 1 & 24.52 & 67.49 & 0.36 & & \\
\hline 21 & 21.9 & 1 & 73.55 & 41.91 & 1.75 & & \\
\hline 22 & 21.91 & 1 & 73.55 & 60.18 & 1.22 & & \\
\hline 23 & 22 & 1 & 137.29 & 67.58 & 2.03 & & \\
\hline 24 & 22.26 & 1 & 24.52 & 65.12 & 0.38 & & \\
\hline 25 & 22.89 & 1 & 58.84 & 63.49 & 0.93 & & \\
\hline 26 & 23.39 & 1 & 49.03 & 42.87 & 1.14 & & \\
\hline 27 & 23.9 & 1 & 9.81 & 47.42 & 0.21 & & \\
\hline 28 & 24 & 1 & 24.52 & 59.08 & 0.41 & & \\
\hline 29 & 24.28 & 1 & 147.1 & 121.87 & 1.21 & & \\
\hline 30 & 26.22 & 1 & 0 & 28.72 & 0 & & \\
\hline 31 & 27.26 & 1 & 0 & 16.99 & 0 & & \\
\hline
\end{tabular}




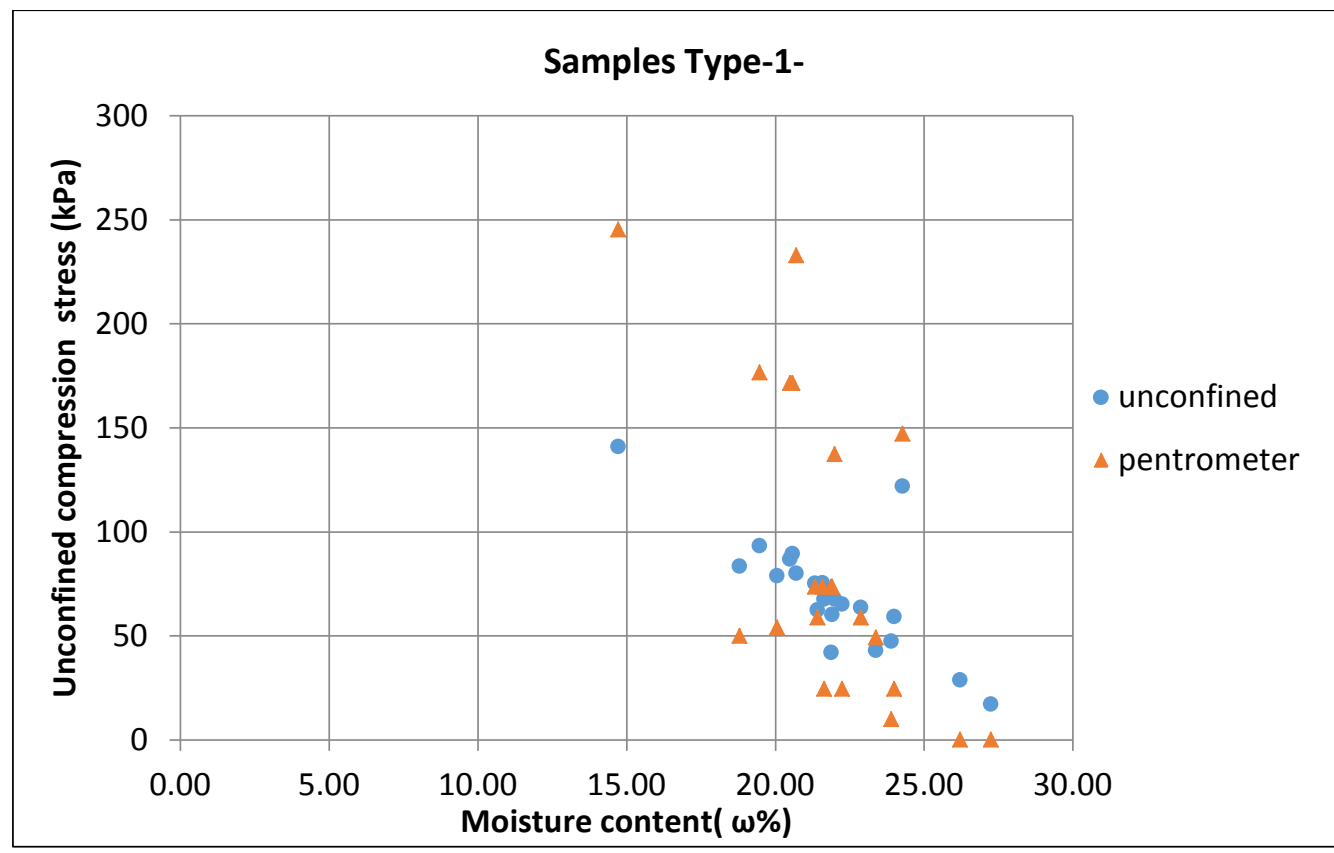

Figure 2: Comparison between penetrometer readings and unconfined compressive strength relative to moisture content samples type-1-

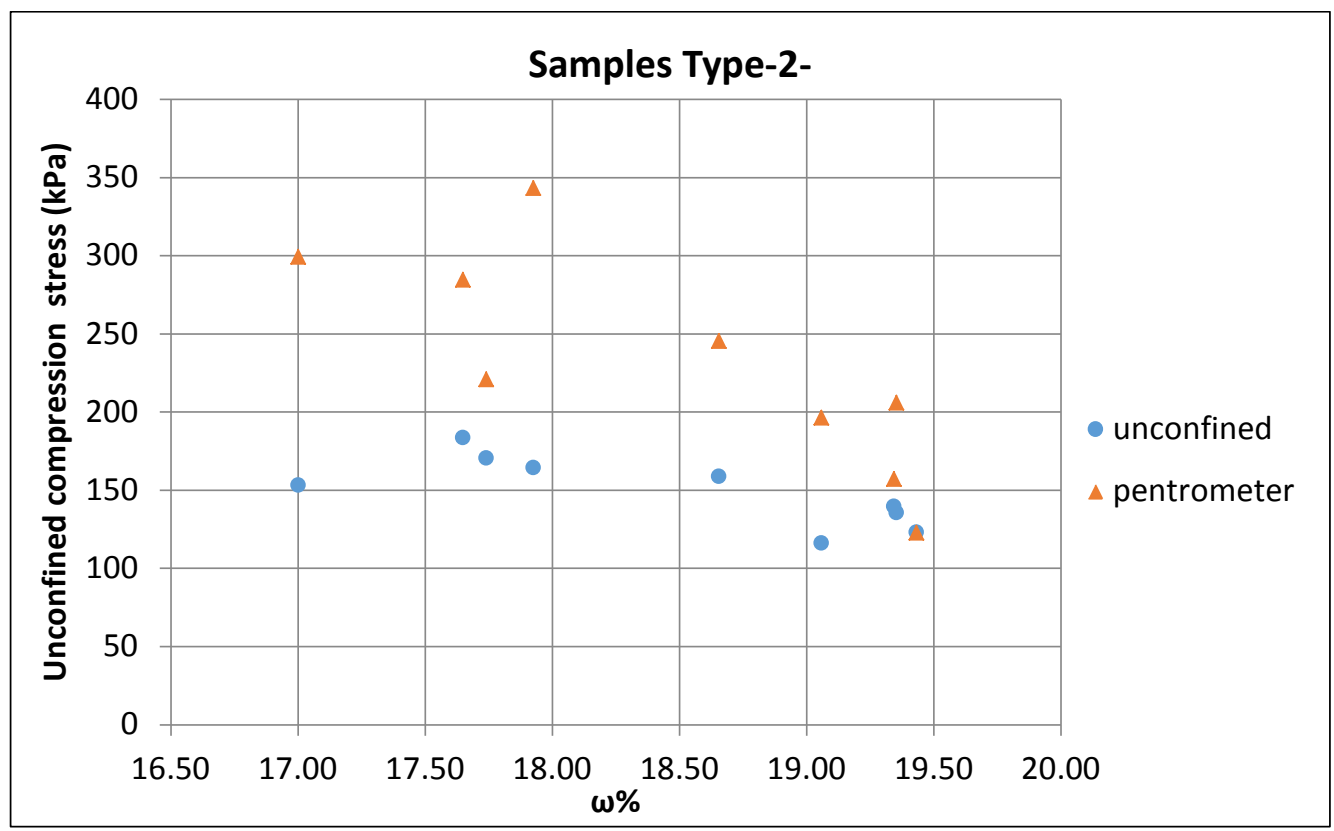

Figure 3: Comparison between penetrometer readings and unconfined compression strength relative to moisture content samples type-2- 


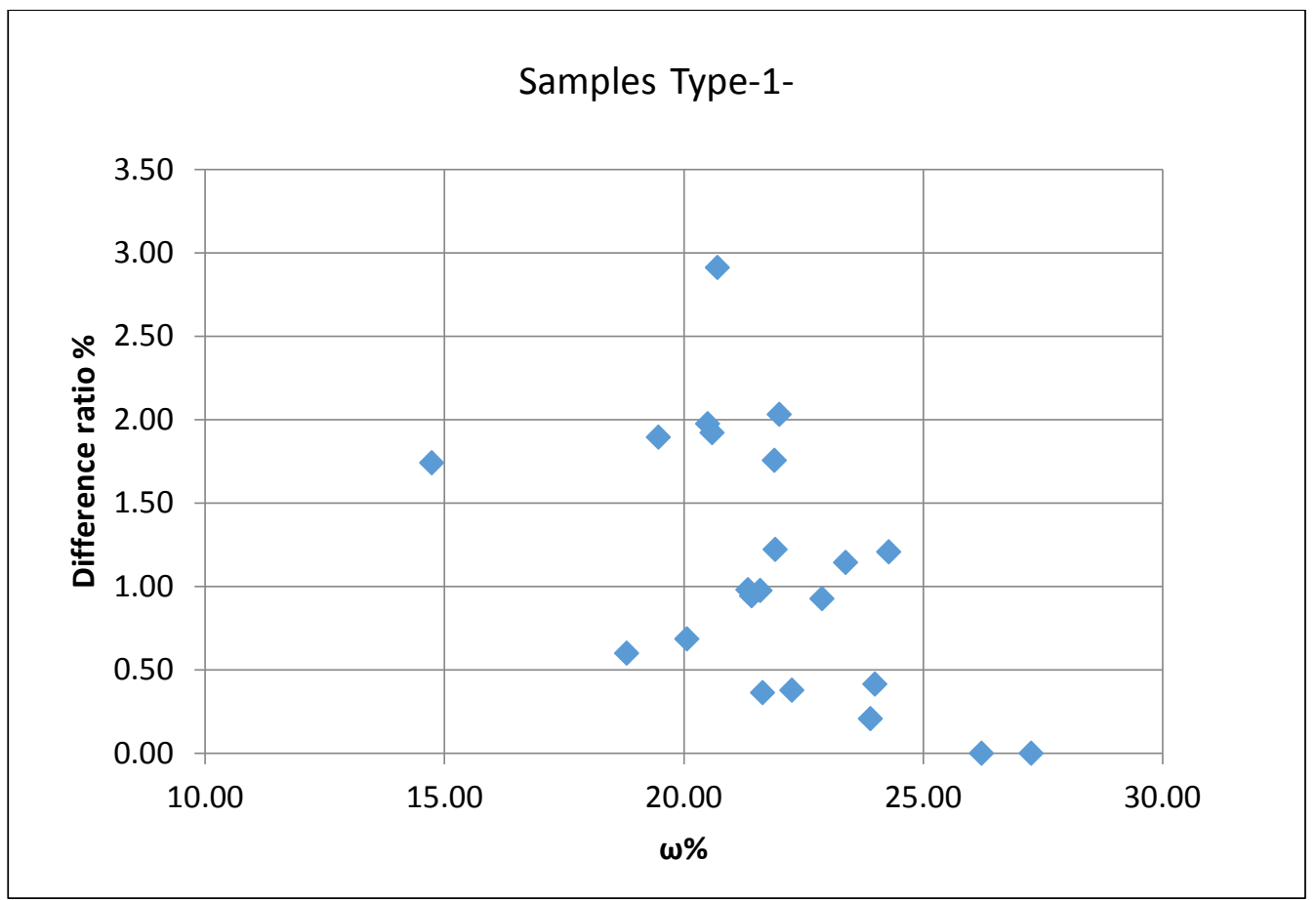

Figure 4: Difference ratio versus soil moisture content samples type-1-

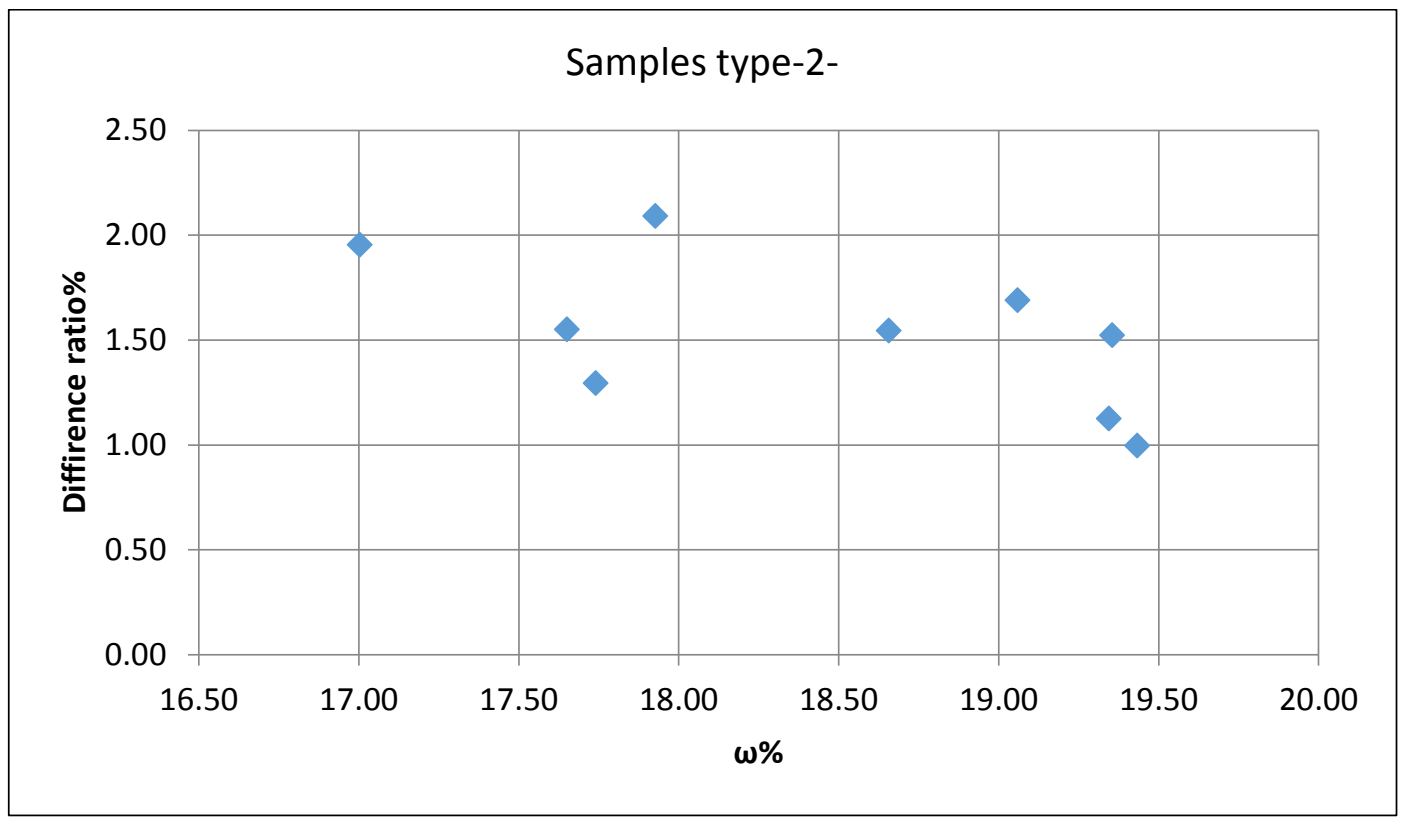

Figure 5: Difference ratio versus soil moisture content samples type-2-

\section{Conclusion}

1- For more accuracy of results the limitation of moisture content for clayey silt soil should be limited between (18-25\%).

2- When the moisture content more than (25\%) the penetrometer tool can be used after increase tip area of pocket penetrometer.
3- The consistency of clayey silt soil become paste as moisture content of soil increased more than (30\%)

4- pocket penetrometer cannot be performed.

5- It was founded that the difference ratios between penetrometer readings and unconfined compressive strength was acceptable.

6- The percentage of error can be reduced as increasing of dimensions of sample. 
7- As moisture content of clayey silt decreased (less than18\%) the spacemen will be crumbled, therefore the pocket penetrometer tool can't be used.

\section{References}

[1] ASTM official website/ www.astm.org, ASTM WK27337, New Test Method for Pocket Penetrometer Test.

[2] Oregon Department Of Transportation,(2016), "laboratory manual of test procedures” construction section materials laboratory,800 airport road.

[3] CH Delegard, AJ Schmidt and JW Chenaul, December 2011, "Strength Measurements of Archive K Basin Sludge Using a Soil Penetrometer".

[4] Texas department of transportation, (1999), "Manual Procedure for Description Identification of Soils", last reviewed: September 2014.

[5] Joseph E. Bowles, RE., S.E,(1996), “ Foundation Analysis And Design”, Fifth Edition, 1230 pages.

[6] Braja M. Das, Dean Emeritus and Khaled Sobhan, Florida Atlantic University,(2014) Principles of Geotechnical Engineering, Eighth Edition, SI,683pages.
[7] ASTM D 2166, Standard Test Method for Unconfined Compressive Strength of Cohesive Soil

[8] Soil penetrometer, pocket style, (2016), Humboldt product manual.

[9] Soil and Rock Logging, Classification, and Presentation Manual 2010 edition, State of California Department of

[10] Transportation Division of Engineering Services Geotechnical Services.

[11] ASTM D 2216, Standard Test Method for Laboratory Determination of Water (Moisture) Content of Soil and Rock by Mass.

[12] ASTM D 4318, Standard Test Methods for Liquid Limit, Plastic Limit, and Plasticity Index of Soils.

[13] ASTM D 854, Standard Test Methods for Specific Gravity of Soil Solids by Water Pycnometer.

[14] ASTM D 698 , Standard Test Methods for Laboratory Compaction Characteristics of Soil Using Standard Effort $(12,400 \mathrm{ft}-$ $\mathrm{lbf} / \mathrm{ft} 3(600 \mathrm{kN}-\mathrm{m} / \mathrm{m} 3))$.

[15] ASTM D 7928, Standard Test Method for Particle-Size Distribution (Gradation) of Fine-Grained Soils Using the Sedimentation (Hydrometer) Analysis.

\section{مطابقة قراعة اداة اختراق التربة لحساب مقاومة الانضغاط غير المحصور لنموذج

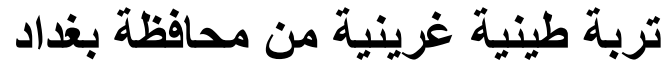$$
\text { أز هر صادق ياسين }
$$$$
\text { قسم الهندسة المدنية }
$$$$
\text { جامعة النهرين }
$$

الخلاصة

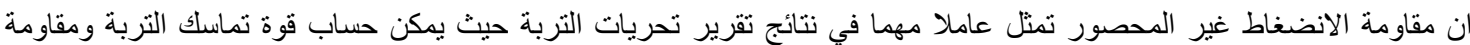

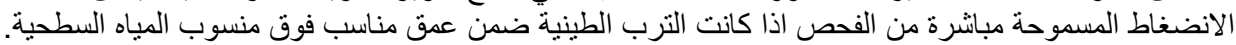

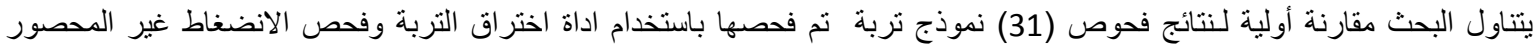

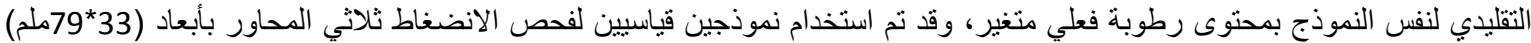

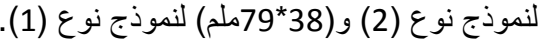

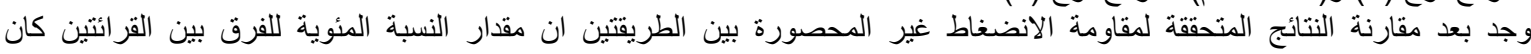

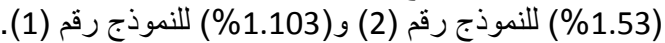

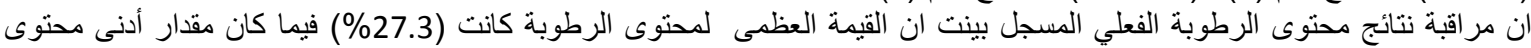

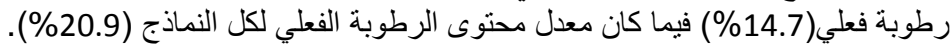

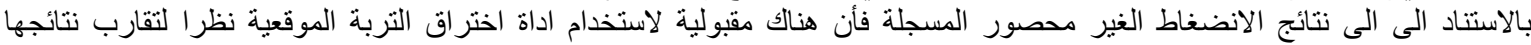

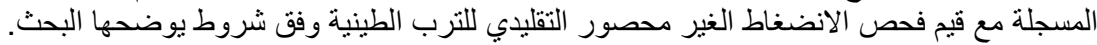

